\title{
Alteromonas stellipolaris sp. nov., a novel, budding, prosthecate bacterium from Antarctic seas, and emended description of the genus Alteromonas
}

\author{
Stefanie Van Trappen, ${ }^{1}$ Tjhing-Lok Tan, ${ }^{2}$ Jifang Yang, ${ }^{2,3}$ Joris Mergaert ${ }^{1}$ \\ and Jean Swings ${ }^{1,4}$
}

Correspondence

Stefanie Van Trappen

stefanie.vantrappen@UGent.be

\author{
${ }^{1}$ Laboratorium voor Microbiologie, Vakgroep Biochemie, Fysiologie en Microbiologie, Universiteit \\ Gent, K.L. Ledeganckstr. 35, B-9000 Gent, Belgium \\ ${ }^{2}$ Alfred-Wegener-Institut für Polar- und Meeresforschung, Bremerhaven, Germany \\ ${ }^{3}$ Second Institute of Oceanography, Hangzhou, China \\ ${ }^{4}$ BCCM/LMG Culture Collection, Universiteit Gent, Belgium
}

\begin{abstract}
Seven novel, cold-adapted, strictly aerobic, facultatively oligotrophic strains, isolated from Antarctic sea water, were investigated by using a polyphasic taxonomic approach. The isolates were Gram-negative, chemoheterotrophic, motile, rod-shaped cells that were psychrotolerant and moderately halophilic. Buds were produced on mother and daughter cells and on prosthecae. Prostheca formation was peritrichous and prosthecae could be branched. Phylogenetic analysis based on 16S rRNA gene sequences indicated that these strains belong to the $\gamma$-Proteobacteria and are related to the genus Alteromonas, with $98 \cdot 3 \%$ sequence similarity to Alteromonas macleodii and $98.0 \%$ to Alteromonas marina, their nearest phylogenetic neighbours. Whole-cell fatty acid profiles of the isolates were very similar and included $\mathrm{C}_{16: 0}$, $\mathrm{C}_{16: 1} \omega 7 c, \mathrm{C}_{17: 1} \omega 8 c$ and $\mathrm{C}_{18: 1} \omega 8 c$ as the major fatty acid components. These results support the affiliation of these isolates to the genus Alteromonas. DNA-DNA hybridization results and differences in phenotypic characteristics show that the strains represent a novel species with a DNA G +C content of 43-45 mol\%. The name Alteromonas stellipolaris sp. nov. is proposed for this novel species; the type strain is ANT $69 a^{\top}\left(=\right.$ LMG $21861^{\top}=$ DSM $\left.15691^{\top}\right)$. An emended description of the genus Alteromonas is given.
\end{abstract}

The genus Alteromonas belongs to the $\gamma$-Proteobacteria and was created by Baumann et al. (1972) for marine, Gramnegative, heterotrophic bacteria that are motile by a single, polar flagellum. On the basis of $16 \mathrm{~S}$ rDNA sequence analysis, the genus was revised in 1995 to contain a single species, Alteromonas macleodii, and the remaining species were reclassified as Pseudoalteromonas (Gauthier et al., 1995). In 1993, the yellow-grey-pigmented species 'Alteromonas rava', which is able to produce a novel antibiotic, was

Published online ahead of print on 19 December 2003 as DOI 10.1099/ijs.0.02862-0.

Abbreviations: L-DOPA, L-3,4-dihydroxyphenylalanine; FAA cluster, fatty acid analysis cluster.

The GenBank/EMBL/DDBJ accession numbers for the 16S rRNA gene sequences of strains LMG $21861^{\top}$, LMG 21856, LMG 21859 , LMG 21860, LMG 21862, LMG 21863 and LMG 21864 are AJ295715, AJ564723, AJ564724, AJ564725, AJ564726, AJ564727 and AJ564728, respectively.

A rep-PCR profile/dendrogram and tables giving strains used in this study and phenotypic characteristics of Alteromonas species are available as supplementary material in IJSEM Online. described (Kodama et al., 1993), but the species name has not yet been validly published. A mesophilic, heterotrophic bacterium, isolated from sea water that was collected near a deep-sea hydrothermal vent, was identified as A. macleodii, but it was classified as a novel subspecies, 'A. macleodii subsp. fijiensis', on the basis of a relatively low DNA-DNA hybridization level $(<90 \%$, but $>70 \%)$, metabolic differences between the type strain and the novel strain, the ability of the novel bacterium to produce a unique exopolysaccharide and the isolation source (Raguénès et al., 1996). The subspecies name 'A. macleodii subsp. fijiensis' has not yet been validly published. Raguénès et al. (1997) proposed a novel Alteromonas species, 'Alteromonas infer$n u s^{\prime}$, for a polysaccharide-producing bacterium that was isolated from the surface of the vestimentiferan worm Riftia pachyptila, which inhabits sites near hydrothermal vents. The name of this novel species, however, has also not been validly published. Romanenko et al. (1994) described a novel species, Alteromonas fuliginea, but phylogenetic analysis based on 16S rDNA sequence data revealed that this species is related more closely to Pseudoalteromonas haloplanktis and it was therefore reclassified as a member 
of the genus Pseudoalteromonas (Yoon et al., 2003). Recently, the name of a novel species that was isolated from the East Sea in Korea (Yoon et al., 2003), Alteromonas marina, has been validly published. Currently, there are only two species with validly published names within the genus Alteromonas, namely A. macleodii (the type species) and A. marina.

The species described here, Alteromonas stellipolaris sp. nov., is a novel, budding, prosthecate bacterium from the $\gamma$-Proteobacteria. Strains of marine, prosthecate, budding bacteria that belong to the genus Hyphomonas, a taxon of the $\alpha$-Proteobacteria, have been described (Weiner et al., 2000), but this is the first report of a budding, prosthecate bacterium from the $\gamma$-Proteobacteria. It is now evident that budding, prosthecate bacteria are abundant in marine and polar environments (Labrenz et al., 1998, 1999; Weiner et al., 2000). Moreover, bud and prosthecate formations are a common strategy for rod-shaped bacteria to enhance their surface: volume ratio, thus enabling the organisms to attain efficient substrate uptakes in oligotrophic habitats (van Gemerden \& Kuenen, 1984).

During expeditions in the Arctic (Tan \& Rüger, 1991) and Antarctic (Tan \& Rüger, 1999) seas, facultatively oligotrophic and psychrotolerant bacteria were isolated. These 173 strains have previously been analysed by substrateutilization patterns using the Biolog system (Tan, 1997; Tan \& Rüger, 1999) and by fatty acid and $16 \mathrm{~S}$ rDNA sequence analyses of representatives (Mergaert et al., 2001). They belong to six metabolic groups and eight different fatty acid analysis (FAA) clusters, each containing between two and 59 strains. In the meantime, 56 additional strains were isolated by using the same methods, analysed by using the Biolog system and their fatty acids were determined. These additional strains belong to clusters B, C, D, E and F [as delineated by Mergaert et al. (2001)] and three new clusters (I, J and K) (S. Van Trappen, unpublished results). The genomic diversity of 19 strains from clusters $\mathrm{E}$ and $\mathrm{F}$ and two related, unclustered strains was investigated further and, by using a polyphasic taxonomic approach, seven Antarctic strains could be assigned to a novel species within the genus Alteromonas, for which the name Alteromonas stellipolaris sp. nov. is proposed.

Antarctic strains were isolated from sea water after an enrichment technique in dialysis chambers as described previously (Tan, 1986, 1997; Tan \& Rüger, 1999). Details of the seven Antarctic strains analysed (with the prefix 'ANT') are available in Supplementary Table A in IJSEM Online, together with their source of isolation. Reference strains LMG $2843^{\mathrm{T}}$ (A. macleodii) and LMG $22057^{\mathrm{T}}$ (A. marina) were included in some experiments. Strains were cultivated routinely on marine agar 2216 (Difco) at $20^{\circ} \mathrm{C}$ for $48 \mathrm{~h}$, except where mentioned otherwise.

The 19 strains of FAA clusters $\mathrm{E}$ and F and two related, unclustered strains were arranged in similarity groups, based on the results of rep-PCR fingerprinting using the $\mathrm{GTG}_{5}$ primer (Versalovic et al., 1991; Rademaker \& de Bruijn, 1997; Rademaker et al., 2000). Numerical analysis was carried out by using the Bionumerics software package, as described by these authors. One cluster of seven Antarctic strains (LMG 21861 ${ }^{\mathrm{T}}$, LMG 21856, LMG 21859, LMG 21860, LMG 21862, LMG 21863 and LMG 21864) that belonged to FAA cluster $\mathrm{E}$ and had almost-identical repPCR profiles could be delineated (data available in the Supplementary Figure in IJSEM Online). 16S rRNA gene sequence analysis revealed that these strains belong to the genus Alteromonas within the $\gamma$-Proteobacteria.

The almost-complete 16S rRNA gene sequence (1482 nt) of strain LMG $21861^{\mathrm{T}}$ was determined as described previously (Mergaert et al., 2001). Partial 16S rRNA gene sequences (735-766 nt) of strains LMG 21856, LMG 21859, LMG 21860, LMG 21862, LMG 21863 and LMG 21864 were determined by Qiagen, Hilden, Germany, using the forward primer $8 \mathrm{~F}$ (5'-AGAGTTTGATCCTGGCTCAG-3') and the reverse primer 1492R (5'-TACGGYTACCTTGTTACGACTT- $\left.3^{\prime}\right)$. The most closely related sequences were found by using the FASTA program. Sequences of reference strains were aligned and editing of the alignment and reformatting were performed with the programs BIOEDIT (Hall, 1999) and FORCON (Raes \& Van de Peer, 1999). Evolutionary distances were calculated by using the evolutionary model of Jukes \& Cantor (1969) and a phylogenetic tree (Fig. 1) was constructed by using the neighbour-joining method with the program TREECON (Van de Peer \& De Wachter, 1994). Dendrograms obtained by maximum-parsimony and maximum-likelihood analyses showed essentially the same topography (data not shown).

The 16S rRNA gene sequence of strain LMG $21861^{\mathrm{T}}$ showed $98.3 \%$ similarity to that of $A$. macleodii, $98 \cdot 0 \%$ to that of

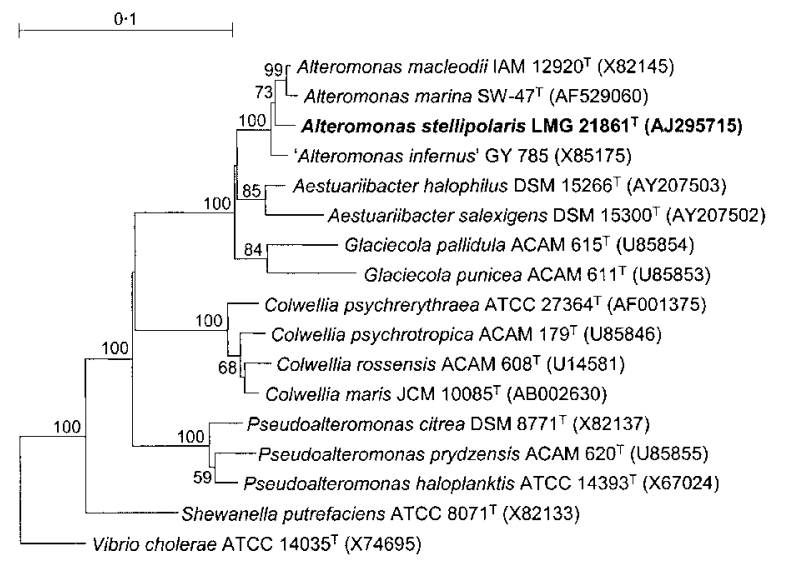

Fig. 1. Neighbour-joining dendrogram showing the estimated phylogenetic relationship between Alteromonas stellipolaris and related marine chemoheterotrophs of the $\gamma$-Proteobacteria. Bootstrap values are shown as percentages of 500 replicates, when $>50 \%$. The GenBank accession number for each reference strain is shown in parentheses. Bar, $1 \mathrm{nt}$ substitution in $100 \mathrm{nt}$. 
A. marina and $97 \cdot 9 \%$ to that of ' $A$. infernus'; the partial sequences of the other Antarctic strains (LMG 21856, LMG 21859, LMG 21860, LMG 21862, LMG 21863 and LMG 21864) were almost identical to each other and to that of strain LMG $21861^{\mathrm{T}}(99 \cdot 5-99 \cdot 8 \%)$. The phylogenetic tree in Fig. 1 shows the distinct branch within the genus Alteromonas that is formed by the novel Antarctic isolates, which is supported by high bootstrap values.

Genomic relatedness between strains LMG $21861^{\mathrm{T}}$ and LMG 21863 and the most closely related strains, A. macleodii LMG $2843^{\mathrm{T}}$ and A. marina LMG $22057^{\mathrm{T}}$, was determined by DNA-DNA hybridization. DNA was prepared according to the method of Pitcher et al. (1989) and DNA-DNA hybridizations were carried out with photobiotin-labelled probes in microplate wells as described by Ezaki et al. (1989), using an HTS7000 BioAssay Reader (Perkin Elmer) for fluorescence measurements. Hybridization temperature was $37^{\circ} \mathrm{C}$ and reciprocal experiments were performed for every pair of strains. DNA hybridization levels of strains LMG $21861^{\mathrm{T}}$ and LMG 21863 with A. macleodii LMG $2843^{\mathrm{T}}$ and A. marina LMG $22057^{\mathrm{T}}$ were very low, with mean values of $12 \cdot 4$ and $15 \cdot 6 \%$, respectively. The DNA-DNA binding value between LMG $21861^{\mathrm{T}}$ and LMG 21863 was high, namely $93.9 \%$, indicating that these strains represent a single species. Indeed, Versalovic et al. (1994) have shown that strains with the same rep-PCR profile are always closely related and this has been confirmed by several authors (e.g. Rademaker \& de Bruijn, 1997). Differences between reciprocal experiments were $<12 \%$. From these hybridization results, it can be concluded that the seven Antarctic isolates are genotypically distinct from A. macleodii and $A$. marina, their phylogenetically nearest neighbours, and thus constitute a novel species within the genus Alteromonas (Wayne et al., 1987).

The DNA G+C content of the Antarctic strains was determined by using an HPLC-based method. DNA was degraded enzymically into nucleosides as described by Mesbah et al. (1989). The obtained nucleoside mixture was then separated by HPLC using a Waters SymmetryShield C8 column that was thermostatted at $37^{\circ} \mathrm{C}$. The solvent was $0.02 \mathrm{M} \mathrm{NH}_{4} \mathrm{H}_{2} \mathrm{PO}_{4}, \mathrm{pH} 4 \cdot 0$, with $1.5 \%$ acetonitrile. Nonmethylated $\lambda$-phage DNA (Sigma) was used as the calibration reference. The DNA G $+\mathrm{C}$ contents of strains LMG $21861^{\mathrm{T}}$, LMG 21856, LMG 21859, LMG 21860, LMG 21862, LMG 21863 and LMG 21864 were $43 \cdot 3,44 \cdot 0,44 \cdot 8$, $44 \cdot 7,44 \cdot 7,43 \cdot 3$ and $44 \cdot 7 \mathrm{~mol} \%$, respectively. These values are consistent with the DNA $\mathrm{G}+\mathrm{C}$ contents of other members of the genus Alteromonas, which range between 44 and $46 \mathrm{~mol} \%$ (Baumann et al., 1972; Yoon et al., 2003).

Cellular fatty acid patterns of the Antarctic strains are based on the data generated by Mergaert et al. (2001) or were determined as described by these authors. The strains showed very similar fatty acid profiles, of which the major constituents included $\mathrm{C}_{16: 0}(12 \cdot 6 \pm 1 \cdot 3 \%$ of total fatty acids), $\mathrm{C}_{17: 1} \omega 8 c(9 \cdot 4 \pm 2 \cdot 3 \%), \mathrm{C}_{18: 1} \omega 7 c(18 \cdot 0 \pm 2 \cdot 1 \%)$ and summed feature $3(27 \cdot 3 \pm 3 \cdot 0 \%)$, which comprises iso- $\mathrm{C}_{15: 0}$ 2-OH and/or $\mathrm{C}_{16: 1} \omega 7 c$. Hydroxylated fatty acids and alcohol derivatives of the fatty acids $\mathrm{C}_{16: 0}$ and $\mathrm{C}_{16: 1} \omega 7 c$ were also present as minor components or at trace levels. The fatty acid profiles of the Antarctic strains clearly resembled those determined for other marine genera of the $\gamma$-Proteobacteria, e.g. Alteromonas, Pseudoalteromonas and Glaciecola (Ivanova et al., 2000; Mikhailov et al., 2002).

The polar strains are Gram-negative, rod-shaped, small cells $(0 \cdot 4 \times 2 \cdot 0-7 \cdot 0 \mu \mathrm{m}$ in length $)$ that possess a single, polar flagellum (Fig. 2). Prosthecae are formed peritrichously and can be branched. Buds can be produced on mother and daughter cells, but also at the end of the prosthecae when grown on peptone/yeast extract/glucose agar [PYG, according to Tan \& Rüger (1999)] at $12^{\circ} \mathrm{C}$ for 7 days (Figs 2 and 3). Strain LMG 21856 releases a brown, diffusible pigment into the medium. This property is shared by several reclassified Alteromonas species (Gauthier \& Breittmayer, 1992) and this brown-black pigment on solid media is often characterized as melanin, a high-molecular-mass, amorphous polymer of indole quinone. The first biosynthesis step involves the hydroxylation of L-tyrosine to form L-3,4-dihydroxyphenylalanine (L-DOPA), which is used in the treatment of Parkinson's disease. Attempts have therefore been made to adapt melanin-producing micro-organisms for the commercial production of L-DOPA. Growth of the strains at different temperatures $\left(5-40^{\circ} \mathrm{C}\right)$ was tested on marine agar 2216 (Difco), whereas salt tolerance was tested on R2A agar (Oxoid) supplemented with $1-20 \% \mathrm{NaCl}$ at $20{ }^{\circ} \mathrm{C}$. The effect of $\mathrm{pH}$ on growth rate was determined at $\mathrm{pH} 5 \cdot 0-10 \cdot 0$ (at intervals of $0.5 \mathrm{pH}$ units) by using tubes that contained $10 \mathrm{ml} 2216 \mathrm{E}$ liquid medium and were incubated at $20^{\circ} \mathrm{C}$ after inoculation. Turbidity was measured by spectrophotometry at $590 \mathrm{~nm}$ (Vitalab 10; Vital Scientific). Biochemical characteristics were determined by using standard protocols (Reichenbach \& Dworkin, 1981; West \& Colwell, 1984; Smibert \& Krieg, 1994; Bowman et al., 1998; Van Trappen et al., 2003) and API kits (API 20E, API 20NE, API ZYM and API32 ID; bioMérieux). Bacterial suspensions were made in sterile, chilled artificial sea water (Instant Ocean synthetic sea salt; Aquarium Systems) and marine agar 2216 (Difco) was used as the basal medium. For Biolog GN2 microplates, cells were grown on PYG agar at $20^{\circ} \mathrm{C}$ for 5 days; cells were then harvested and suspended in 'inoculating fluid'. The salinity of the inoculating fluid was adjusted to $26 \%$ with $\mathrm{NaCl}$. The microplates were incubated at $20^{\circ} \mathrm{C}$ and substrate utilizations were measured after 3, 5, 7, 14, 21 and 28 days at $590 \mathrm{~nm}$ with an eightcanal photometer (Spectra 2; SLT Labinstruments). Methyl pyruvate, L-asparagine, L-aspartic acid and glycyl-L-aspartic acid were utilized by the seven strains if the microplates were incubated at $12^{\circ} \mathrm{C}$ [see cluster 3 of Tan \& Rüger (1999)].

For most characteristics, all strains were identical (see species description) and had properties that are typical for species of the genera Alteromonas and Pseudoalteromonas of the $\gamma$-Proteobacteria (Baumann et al., 1972).

The Antarctic strains can be differentiated from their nearest 

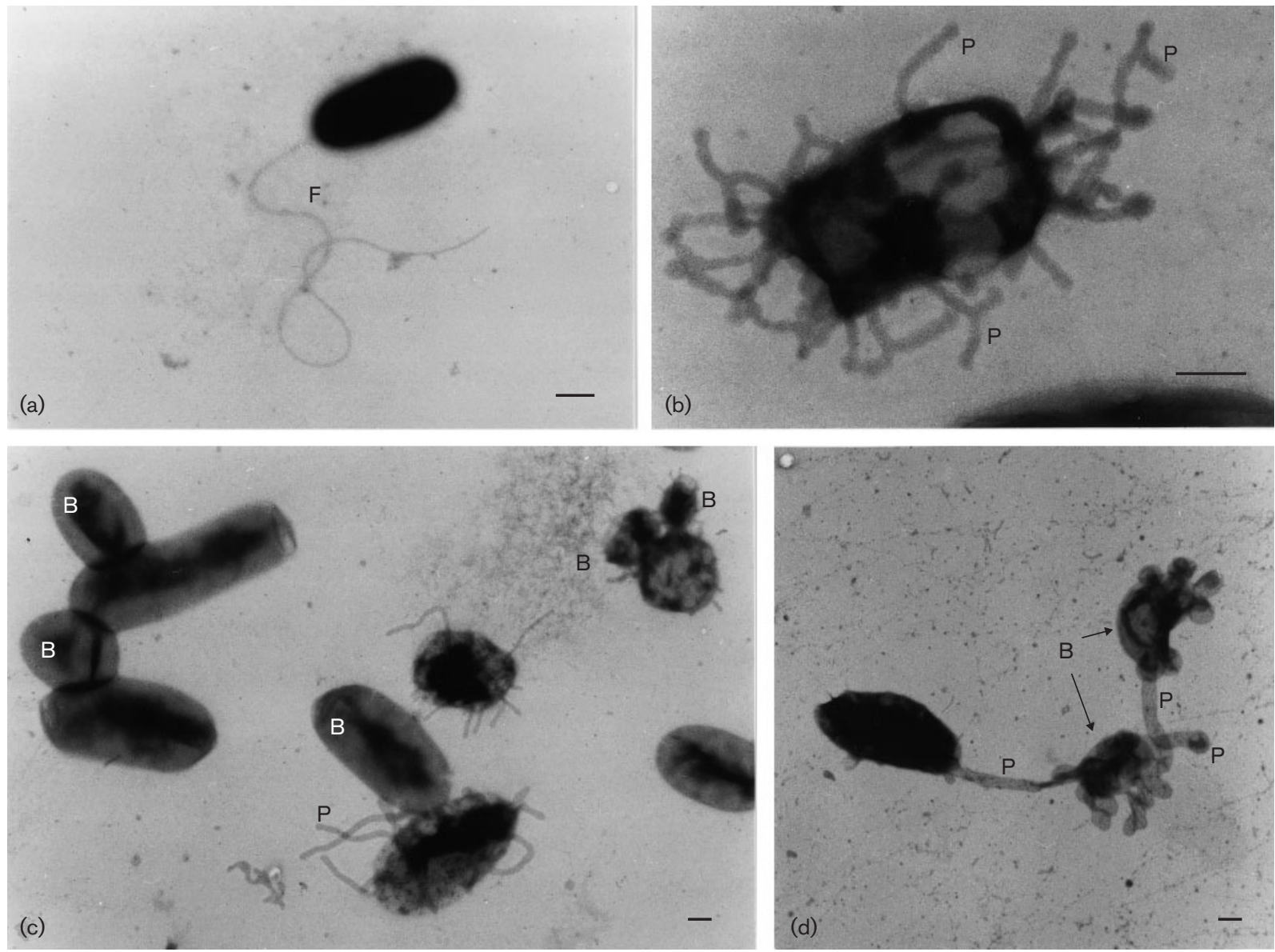

Fig. 2. Electron micrographs of negatively stained preparations of cells of strains: (a) LMG 21859, (b) LMG 21863, (c) LMG 21856 and (d) $L M G 21861^{\top}$, showing a polar flagellum $(F)$, prosthecae $(P)$ and buds $(B)$. Colonies used for analysis were grown on PYG agar at $12{ }^{\circ} \mathrm{C}$ for 7 days. Cells were stained with $1 \%$ uranyl acetate in $0.4 \%$ sucrose. Bars, $300 \mathrm{~nm}$.

phylogenetic neighbours, A. macleodii and A. marina, by several phenotypic characteristics (see Supplementary Table B in IJSEM Online). On the basis of this polyphasic taxonomic study, the Antarctic strains can be assigned to a novel species, for which the name Alteromonas stellipolaris sp. nov. is proposed. Our results also require emendation of the genus Alteromonas with regard to cell morphology.

\section{Emended description of the genus Alteromonas Baumann et al. 1972 (Approved Lists 1980) emend. Gauthier et al. 1995}

The description is as given by Gauthier et al. (1995) with the following additional morphological features. When grown on marine or PYG agar at low temperatures $\left(12-20{ }^{\circ} \mathrm{C}\right)$ for 3 or more days, cells of A. macleodii LMG $2843^{\mathrm{T}}$, A. marina LMG $22057^{\mathrm{T}}$ and A. stellipolaris LMG $21861^{\mathrm{T}}$, LMG 21856, LMG 21859, LMG 21860 and LMG 21863 produce buds and prosthecae (see Figs 2, 3 and 4). Cells of $A$. macleodii and A. marina form only short, straight prosthecae; branching is not observed (Fig. 4).

\section{Description of Alteromonas stellipolaris sp. nov.}

Alteromonas stellipolaris [stel.li.po.la' ris. L. fem. n. stella star; L. adj. polaris polar; N.L. gen. n. stellipolaris referring to the Polarstern (AWI, Bremerhaven), the name of the vessel that was used to collect the samples from which the organisms were isolated].

Cells are Gram-negative, short rods $(0 \cdot 4 \times 2 \cdot 0-7 \cdot 0 \mu \mathrm{m})$ with a single, polar flagellum. Prosthecae are produced peritrichously and can be branched. Buds can be formed on mother and daughter cells and also at the end of the prostheca. Forms creamy-white, circular, flat to low convex, shiny, opaque and slimy colonies that are slightly adherent to agar, with entire margins and a diameter of $2-5 \mathrm{~mm}$ on marine agar plates after 3 days incubation at $20^{\circ} \mathrm{C}$. Growth occurs on marine agar and PYG agar; slight growth is observed on nutrient agar, but no growth is seen on trypticase soy agar or R2A agar. Strain LMG 21856 releases a brown, diffusible pigment into the medium. Temperature 

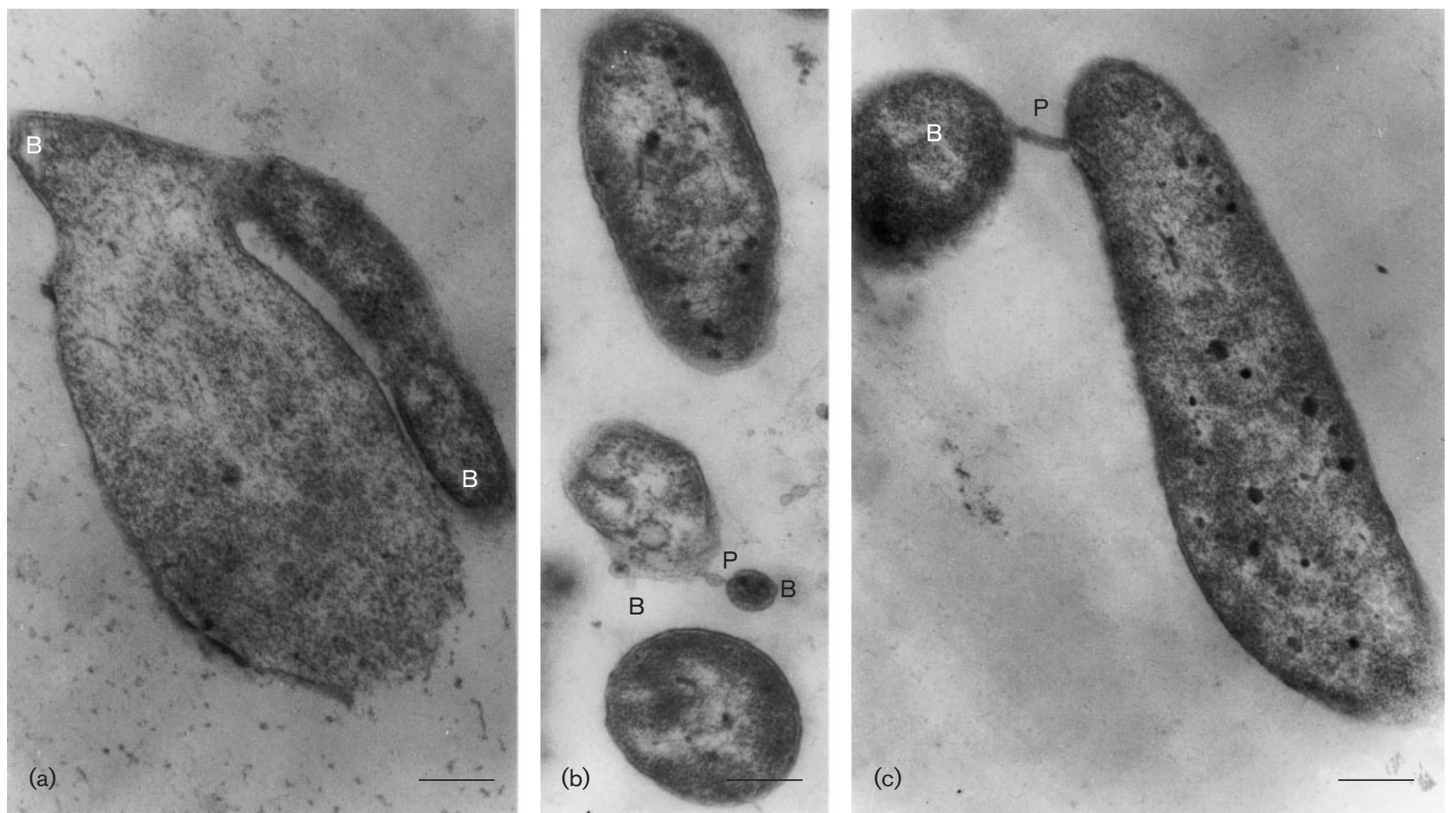

Fig. 3. Electron micrographs of thin-section preparations of cells of strains (a, c) LMG $21861^{\top}$ and (b) LMG 21860 , showing bud $(B)$ formations not only on the cell surface, but also at the end of the prostheca $(P)$. Colonies used for analysis were grown on PYG agar at $12{ }^{\circ} \mathrm{C}$ for 7 days. Thin-section preparations were stained with lead citrate and $1 \%$ uranyl acetate. Bars, $300 \mathrm{~nm}$.
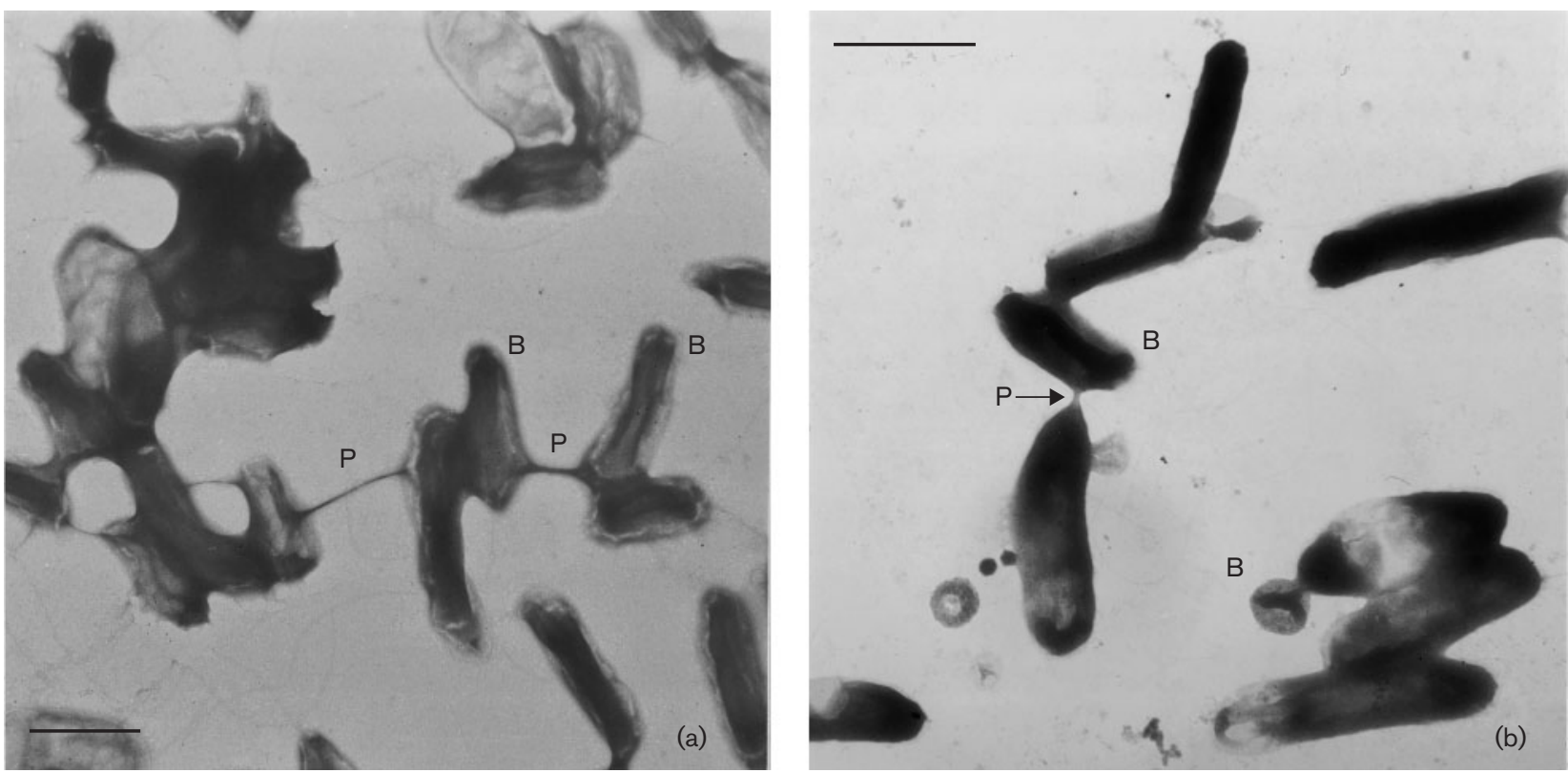

Fig. 4. Electron micrographs of negatively stained preparations of cells of (a) Alteromonas macleodii and (b) Alteromonas marina, showing prosthecae $(P)$ and buds $(B)$. Colonies used for analysis were grown on marine agar at $20^{\circ} \mathrm{C}$ for 12 days or on PYG agar at $20^{\circ} \mathrm{C}$ for 3 days. Cells were stained with $1 \%$ uranyl acetate in $0.4 \%$ sucrose. Bars, $1000 \mathrm{~nm}$. 
range for growth is $5-37^{\circ} \mathrm{C}$; no growth occurs at $40{ }^{\circ} \mathrm{C}$ or higher. Growth is supported on R2A agar that contains $1-10 \% \mathrm{NaCl}$. Moderately halophilic and psychrotolerant. Growth occurs at $\mathrm{pH} 6-9$; optimum $\mathrm{pH}$ for growth is $7 \cdot 0-8 \cdot 5$. No evidence is found for growth under anaerobic conditions. Catalase and cytochrome oxidase tests are positive. Polyhydroxybutyrate is not accumulated and spores are not formed. Egg-yolk precipitation is positive for some strains (LMG $21861^{\mathrm{T}}$, LMG 21856, LMG 21860, LMG 21862 and LMG 21863). Negative for indole and acetoin production, Voges-Proskauer test, citrate utilization, hydrolysis of urea, nitrate reduction and production of hydrogen sulfide. Degradation of starch, aesculin, gelatin and DNA is positive for all strains and $\beta$-galactosidase activity is detected. All strains are able to utilize Tween 40, Tween 80, D-fructose, D-galactose, gentiobiose, $\alpha$-D-glucose, maltose, D-mannitol, D-melibiose, D-trehalose, furanose, acetic acid, propionic acid, alaninamide, L-alanyl-glycine, L-glutamic acid and glycyl-L-glutamic acid; all strains except LMG 21862 are able to utilize dextrin, $\alpha$-D-lactose, lactulose, D-raffinose, sucrose, D-galacturonic acid and $\beta$ hydroxybutyric acid; all strains except LMG 21864 are able to utilize glycogen; all strains except LMG 21863 are able to utilize cellobiose; all strains except LMG 21860 are able to utilize D-mannose; all strains except LMG 21859 are able to utilize D-psicose. Variable results are obtained for $\alpha$-cyclodextrin, methyl $\beta$-D-glucose, D-gluconic acid, $\alpha$-ketobutyric acid, succinic acid, L-alanine, L-leucine, L-proline, L-serine, L-threonine, inosine, uridine and glycerol. No metabolic activity is observed on adonitol, L-arabinose, D-arabitol, $N$-acetylglucosamine, $N$-acetylgalactosamine, isoerythritol, L-fucose, meso-inositol, L-rhamnose, D-sorbitol, xylitol, methyl pyruvate, monomethyl succinate, cis-aconitic acid, citric acid, formic acid, D-galactonic acid lactone, D-glucosaminic acid, D-glucuronic acid, $\alpha$-hydroxybutyric acid, $\gamma$-hydroxybutyric acid, $p$-hydroxyphenylacetic acid, itaconic acid, $\alpha$-ketoglutaric acid, $\alpha$-ketovaleric acid, DL-lactic acid, malonic acid, quinic acid, D-saccharic acid, sebacic acid, bromosuccinic acid, succinamic acid, glucuronamide, D-alanine, L-asparagine, L-aspartic acid, glycyl L-aspartic acid, L-histidine, hydroxy-L-proline, Lornithine, L-phenylalanine, L-pyroglutamic acid, D-serine, DL-carnitine, $\gamma$-aminobutyric acid, urocanic acid, thymidine, phenylethylamine, putrescine, 2-aminoethanol, 2,3butanediol, DL- $\alpha$-glycerolphosphate, glucose 1-phosphate or glucose 6-phosphate. Acids are produced from amygdalin in a clear positive reaction, whereas an intermediate positive reaction is detected for mannitol, sucrose and melibiose for all strains. No acids are produced from glucose, inositol, sorbitol, rhamnose or arabinose. Degradation of alginate and chitin is negative. No arginine dihydrolase, lysine decarboxylase, ornithine decarboxylase, tryptophan deaminase, cystine arylamidase, $\alpha$-chymotrypsin, $\beta$-glucuronidase, $\beta$-glucosidase, $N$-acetyl- $\beta$-glucosaminidase, $\alpha$-mannosidase or $\alpha$-fucosidase activities are observed. For all strains, low activity (score 1) or no activity is obtained for lipase (C14), medium activity (score 2 or 3 ) is obtained for esterase (C4), esterase lipase (C8), valine arylamidase, trypsin and $\alpha$-galactosidase, and high activity (score 4 or 5 ) is obtained for alkaline phosphatase, leucine arylamidase, acid phosphatase, naphthol-AS-BI-phosphohydrolase, $\beta$ galactosidase and $\alpha$-glucosidase. Cells contain the fatty acids $\mathrm{C}_{16: 0}, \mathrm{C}_{16: 1} \omega 7 c, \mathrm{C}_{17: 1} \omega 8 c$ and $\mathrm{C}_{18: 1} \omega 8 c$ as the main constituents. DNA G+C content of the strains is 43-45 mol\%.

The type strain is LMG $21861^{\mathrm{T}}\left(=\right.$ ANT $\left.69 \mathrm{a}^{\mathrm{T}}=\mathrm{DSM} 15691^{\mathrm{T}}\right)$.

\section{Acknowledgements}

This work was funded by the 'Bijzonder Onderzoeksfonds' (BOF), Universiteit Gent, Belgium. We acknowledge A. Mädler and S. Spahic for technical assistance.

\section{References}

Baumann, L., Baumann, P., Mandel, M. \& Allen, R. D. (1972). Taxonomy of aerobic marine eubacteria. J Bacteriol 110, 402-429.

Bowman, J. P., McCammon, S. A., Brown, J. L. \& McMeekin, T. A. (1998). Glaciecola punicea gen. nov., sp. nov. and Glaciecola pallidula gen. nov., sp. nov.: psychrophilic bacteria from Antarctic sea-ice habitats. Int J Syst Bacteriol 48, 1213-1222.

Ezaki, T., Hashimoto, Y. \& Yabuuchi, E. (1989). Fluorometric deoxyribonucleic acid-deoxyribonucleic acid hybridization in microdilution wells as an alternative to membrane filter hybridization in which radioisotopes are used to determine genetic relatedness among bacterial strains. Int J Syst Bacteriol 39, 224-229.

Gauthier, M. J. \& Breittmayer, V. A. (1992). The genera Alteromonas and Marinomonas. In The Prokayotes, 2nd edn, vol. 3, pp. 30463070. Edited by A. Balows, H. G. Trüper, M. Dworkin, W. Harder \& K.-H. Schleifer. New York: Springer.

Gauthier, G., Gauthier, M. \& Christen, R. (1995). Phylogenetic analysis of the genera Alteromonas, Shewanella, and Moritella using genes coding for small-subunit rRNA sequences and division of the genus Alteromonas into two genera, Alteromonas (emended) and Pseudoalteromonas gen. nov., and proposal of twelve new species combinations. Int J Syst Bacteriol 45, 755-761.

Hall, T. A. (1999). BIOEDIT: a user-friendly biological sequence alignment editor and analysis program for Windows 95/98/NT. Nucleic Acids Symp Ser 41, 95-98.

Ivanova, E. P., Zhukova, N. V., Svetashev, V. I., Gorshkova, N. M., Kurilenko, V. V., Frolova, G. M. \& Mikhailov, V. V. (2000). Evaluation of phospholipid and fatty acid compositions as chemotaxonomic markers of Alteromonas-like proteobacteria. Curr Microbiol 41, 341-345.

Jukes, T. H. \& Cantor, C. R. (1969). Evolution of protein molecules. In Mammalian Protein Metabolism, pp. 21-132. Edited by H. N. Munro. New York: Academic Press.

Kodama, K., Shiozawa, H. \& Ishii, A. (1993). Alteromonas rava sp. nov., a marine bacterium that produces a new antibiotic, thiomarinol. Ann Rep Sankyo Res Lab 45, 131-136.

Labrenz, M., Collins, M. D., Lawson, P. A., Tindall, B. J., Braker, G. \& Hirsch, P. (1998). Antarctobacter heliothermus gen. nov., sp. nov., a budding bacterium from hypersaline and heliothermal Ekho Lake. Int J Syst Bacteriol 48, 1363-1372.

Labrenz, M., Collins, M. D., Lawson, P. A., Tindall, B. J., Schumann, P. \& Hirsch, P. (1999). Roseovarius tolerans gen. nov., sp. nov., a budding bacterium with variable bacteriochlorophyll a production from hypersaline Ekho Lake. Int J Syst Bacteriol 49, 137-147. 
Mergaert, J., Verhelst, A., Cnockaert, M. C., Tan, T.-L. \& Swings, J. (2001). Characterization of facultative oligotrophic bacteria from polar seas by analysis of their fatty acids and $16 \mathrm{~S}$ rDNA sequences. Syst Appl Microbiol 24, 98-107.

Mesbah, M., Premachandran, U. \& Whitman, W. B. (1989). Precise measurement of the $\mathrm{G}+\mathrm{C}$ content of deoxyribonucleic acid by highperformance liquid chromatography. Int J Syst Bacteriol 39, 159-167.

Mikhailov, V. V., Romanenko, L. A. \& Ivanova, E. P. (2002). The genus Alteromonas and related Proteobacteria. In The Prokaryotes: an Evolving Electronic Resource for the Microbiological Community. Edited by M. Dworkin, E. Rosenberg, K. H. Schleifer \& E. Stackebrandt. New York: Springer (http://141.150.157.117:8080/ prokPUB/chaprender/jsp/showchap.jsp?chapnum $=390)$.

Pitcher, D. G., Saunders, N. A. \& Owen, R. J. (1989). Rapid extraction of bacterial genomic DNA with guanidium thiocyanate. Lett Appl Microbiol 8, 151-156.

Rademaker, J. L. W. \& de Bruijn, F. J. (1997). Characterization and classification of microbes by rep-PCR genomic fingerprinting and computer-assisted pattern analysis. In DNA Markers: Protocols, Applications, and Overviews, pp. 151-171. Edited by G. CaetanoAnollés \& P. M. Gresshoff. New York: Wiley.

Rademaker, J. L. W., Hoste, B., Louws, F. J., Kersters, K., Swings, J., Vauterin, L., Vauterin, P. \& de Bruijn, F. J. (2000). Comparison of AFLP and rep-PCR genomic fingerprinting with DNA-DNA homology studies: Xanthomonas as a model system. Int J Syst Evol Microbiol 50, 665-677.

Raes, J. \& Van de Peer, Y. (1999). FORCON: a software tool for the conversion of sequence alignments (http://www.ebi.ac.uk/embnet. news/vol6_1/ForCon/body_forcon.html).

Raguénès, G., Pignet, P., Gauthier, G., Peres, A., Christen, R., Rougeaux, H., Barbier, G. \& Guezennec, J. (1996). Description of a new polymer-secreting bacterium from a deep-sea hydrothermal vent, Alteromonas macleodii subsp. fijiensis, and preliminary characterization of the polymer. Appl Environ Microbiol 62, 67-73.

Raguénès, G. H. C., Peres, A., Ruimy, R., Pignet, P., Christen, R., Loaec, M., Rougeaux, H., Barbier, G. \& Guezennec, J. G. (1997). Alteromonas infernus sp. nov., a new polysaccharide-producing bacterium isolated from a deep-sea hydrothermal vent. J Appl Microbiol 82, 422-430.

Reichenbach, H. \& Dworkin, M. (1981). Introduction to the gliding bacteria. In The Prokaryotes, vol. 1, pp. 315-327. Edited by M. P. Starr, H. Stolp, H. G. Trüper, A. Balows \& H. G. Schlegel. Berlin: Springer.

Romanenko, L. A., Lysenko, A. M., Mikhailov, V. V. \& Kurika, A. V. (1994). A new species of brown-pigmented agarolytic bacteria of the genus Alteromonas. Microbiology (English translation of Mikrobiologiya) 63, 1081-1087.

Smibert, R. M. \& Krieg, N. R. (1994). Phenotypic characterization. In Methods for General and Molecular Bacteriology, pp. 607-655.
Edited by P. Gerhardt, R. G. E. Murray, W. A. Wood \& N. R. Krieg. Washington, DC: American Society for Microbiology.

Tan, T. L. (1986). Construction and use of a dialysis chamber for investigating in situ the toxicity of heavy metals on bacteria. IFREMER Actes de Colloques 3, 589-595.

Tan, T. L. (1997). Biolog metabolic fingerprints for clustering marine oligotrophic bacteria from polar regions. In Microbial Communities Functional versus Structural Approaches, pp. 161-170. Edited by H. Insam \& A. Rangger. Berlin: Springer.

Tan, T. L. \& Rüger, H.-J. (1991). Biomass and nutritional requirements of psychrotrophic bacterial communities in Fram Strait and western Greenland Sea. Kiel Meeresforsch Sonderh 8, 219-224.

Tan, T. L. \& Rüger, H.-J. (1999). Enrichment, isolation, and Biolog metabolic fingerprints of oligotrophic bacteria from the Antarctic Ocean. Arch Hydrobiol Spec Issues 54, 255-272.

Van de Peer, Y. \& De Wachter, R. (1994). TREECON for Windows: a software package for the construction and drawing of evolutionary trees for the Microsoft Windows environment. Comput Appl Biosci 10, 569-570.

van Gemerden, H. \& Kuenen, J. G. (1984). Strategies for growth and evolution of microorganisms in oligotrophic habitats. In Heterotrophic Activity in the Sea. NATO Conference Series IV. Marine Sciences, vol. 15, pp. 25-54. Edited by J. E. Hobbie \& P. J. Williams. New York: Plenum.

Van Trappen, S., Mergaert, J. \& Swings, J. (2003). Flavobacterium gelidilacus sp. nov., isolated from microbial mats in Antarctic lakes. Int J Syst Evol Microbiol 53, 1241-1245.

Versalovic, J., Koeuth, T. \& Lupski, J. R. (1991). Distribution of repetitive DNA sequences in eubacteria and application to fingerprinting of bacterial genomes. Nucleic Acids Res 19, 6823-6831.

Versalovic, J., Schneider, M., de Bruijn, F. J. \& Lupski, J. R. (1994). Genomic fingerprinting of bacteria using repetitive sequence-based polymerase chain reaction. Methods Mol Cell Biol 5, 25-40.

Wayne, L. G., Brenner, D. J., Colwell, R. R. \& 9 other authors (1987). International Committee on Systematic Bacteriology. Report of the ad hoc committee on reconciliation of approaches to bacterial systematics. Int J Syst Bacteriol 37, 463-464.

Weiner, R. M., Melick, M., O'Neill, K. \& Quintero, E. (2000). Hyphomonas adhaerens sp. nov., Hyphomonas johnsonii sp. nov. and Hyphomonas rosenbergii sp. nov., marine budding and prosthecate bacteria. Int J Syst Evol Microbiol 50, 459-469.

West, P. A. \& Colwell, R. R. (1984). Identification and classification of the Vibrionaceae - an overview. In Vibrios in the Environment, pp. 285-363. Edited by R. R. Colwell. New York: Wiley.

Yoon, J.-H., Kim, I.-G., Kang, K. H., Oh, T.-K. \& Park, Y.-H. (2003). Alteromonas marina sp. nov., isolated from sea water of the East Sea in Korea. Int J Syst Evol Microbiol 53, 1625-1630. 